\begin{tabular}{|c|c|c|c|}
\hline$D E$ & \multirow{3}{*}{$\begin{array}{l}\text { DE GRUYTER } \\
\text { OPEN }\end{array}$} & $\begin{array}{l}\text { HUNGARIAN JOURNAL OF } \\
\text { INDUSTRY AND CHEMISTRY }\end{array}$ & \multirow[t]{3}{*}{$\begin{array}{l}\text { HUNAGARIAN JOURNALI OI } \\
\text { INIDUSTIRY ANID CIIIEMISTIRSY }\end{array}$} \\
\hline & & Vol. 43(1) pp. 19-23 (2015) & \\
\hline & & $\begin{array}{l}\text { hjic.mk.uni-pannon.hu } \\
\text { DOI: 10.1515/hjic-2015-0004 }\end{array}$ & \\
\hline
\end{tabular}

\title{
EVALUATION OF THE HEAVY METAL CONTENT OF THE UPPER TISZA RIVER FLOODPLAIN SOILS OVER THE LAST DECADE
}

\author{
ZOLTÁN GYÖRI, ${ }^{1 *}$ NORBERT BOROS, ${ }^{2}$ PÉTER SiPOS, ${ }^{2}$ EMESE BERTÁNÉ SZABÓ, ${ }^{2}$ \\ KATALIN KOVÁCS, ${ }^{3}$ MÁRK HORVÁTH, ${ }^{3}$ ANITA TAKÁCS, ${ }^{3}$ AND GYÖRGY HELTAI ${ }^{3}$ \\ ${ }^{1}$ Institute of Regional Economics and Rural Development, Szent István University, Páter K. u. 1, \\ Gödöllö, 2100, HUNGARY \\ 2 Institute of Food Science, University of Debrecen, Böszörményi u. 138, Debrecen, 4032 , \\ HUNGARY \\ ${ }^{3}$ Department of Biochemistry and Chemistry, Szent István University, Páter K. u. 1, Gödöllö, 2100, \\ HUNGARY
}

\begin{abstract}
In early 2000, two contamination events at Baia Mare first and Baia Borsa second involving large amounts of toxic elements impacted the Hungarian section of the River Tisza with disastrous ecological and economical impacts. We evaluated the sort- and long-term effects of this pollution by determining the total and bioavailable concentrations of potentially toxic metals from soil samples collected along the Tisza (Tivadar, Vásárosnamény, Rakamaz, and Tiszacsege) in 2000 and between 2011 and 2013. The current and previous results were compared in respect of copper and lead contents.
\end{abstract}

Keywords: River Tisza, floodplain soils, heavy metal pollution, Lakanen-Erviö extraction, nitric acid/peroxide extraction

\section{Introduction}

There were intensive $\mathrm{Cu}, \mathrm{Zn}, \mathrm{Pb}, \mathrm{Au}$, and $\mathrm{Ag}$ mining activities during early 2000 in the catchment area of the River Tisza [1]. In the last two decades of the previous century, the processing of tailings pond using cyanide was popular as a recovery technology. The resulting wastewaters contain fine-grained sediments with heavy metal contents [2].

In early 2000, two contamination events (at Baia Mare first and Baia Borsa second) involved the release of large amounts of toxic elements that impacted the Hungarian section of the River Tisza with disastrous ecological and economical consequences. The first one released $100,000 \mathrm{~m}^{3}$ wastewater that contaminated with cyanide and heavy metals the river Tisza via its tributary Lápos-Szamos. The second disaster sent about 20,000 tons of mud containing heavy metals into the river Lápos-Tisza along with a simultaneous flood settling, forming a layer of approximately $5-10 \mathrm{~cm}$ in depth on the pre-existing soil [3-8]. Metals were primarily bound to floating material and deposited in floodplain areas.

The metal pollution of the floodplains was also observable $[9,10]$. The environmental risk of this type of soil contamination is that the buffer capacity of new layer is smaller than the previously and the potential

*Correspondence: gyori.zoltan@gtk.szie.hu decreases in $\mathrm{pH}$ enhance metal bioavailability and toxicity. The mobility and phytoavailability of metals depend on their chemical forms [11]. The speciation justifies the use of sequential extraction method (SEP) for analyzing these soil samples.

Considering the above information, it is likely that the residual heavy metal load may entail economic effects that cannot be envisaged at the moment as the valley of River Tisza is under agricultural use (pastures, meadows, orchards, and arable land). This is the reason why intensive research has aimed at testing and monitoring the ecological systems of both water and floodplains. This paper presents only the vertical distribution and forms of heavy metals in polluted areas, although plant relations were also examined [6]. The aim of this study was to evaluate the effects of these sources of pollution on the total and bioavailable metal contents of soil samples collected in 2000 and between 2011 and 2013 from floodplains and pastures along the Tisza (Tivadar, Vásárosnamény, Rakamaz, and Tiszacsege) and compare these results to earlier ones.

\section{Materials and Methods}

Soil samples were collected in 2000 after the flood and in April 2011 and September 2013 by deep drilling using a Nordmeyer drill (Nordmeyer Holland, Overveen, The Netherlands). We sampled the 3 m-deep soil layer in triplicates. Sampling sites are represented in Table 1. 
Table 1. Summary of sampling sites.

\begin{tabular}{lllll}
\hline Sampling sites & $\begin{array}{l}\text { Geographical } \\
\text { coordinates }\end{array}$ & $\begin{array}{l}\text { River } \\
\mathrm{km}\end{array}$ & Types of samples & Additional information \\
\hline Tivadar & $\mathrm{N} 48^{\circ} 04^{\prime} 00.6^{\prime \prime}$ & 709 & active floodplain & affected by the second pollution event \\
& $\mathrm{E} 22^{\circ} 31^{\prime} 04.8^{\prime \prime}$ & & & \\
Vásárosnamény & $\mathrm{N} 48^{\circ} 07^{\prime} 46.5^{\prime \prime}$ & 683 & pasture & affected by the first and second pollution events \\
& $\mathrm{E} 22^{\circ} 19^{\prime} 39.5^{\prime \prime}$ & & & \\
Rakamaz & $\mathrm{N} 48^{\circ} 07^{\prime} 43.8^{\prime \prime}$ & 543 & pasture & affected by the first and second pollution events \\
& $\mathrm{E} 21^{\circ} 26^{\prime} 28.7^{\prime \prime}$ & & & \\
Tiszacsege & $\mathrm{N} 47^{\circ} 42^{\prime} 59.9^{\prime \prime}$ & 455 & active floodplain & $\begin{array}{l}\text { affected by the first and second pollution events } \\
8 \text { years ago the area was refilled with soil }\end{array}$ \\
\hline
\end{tabular}

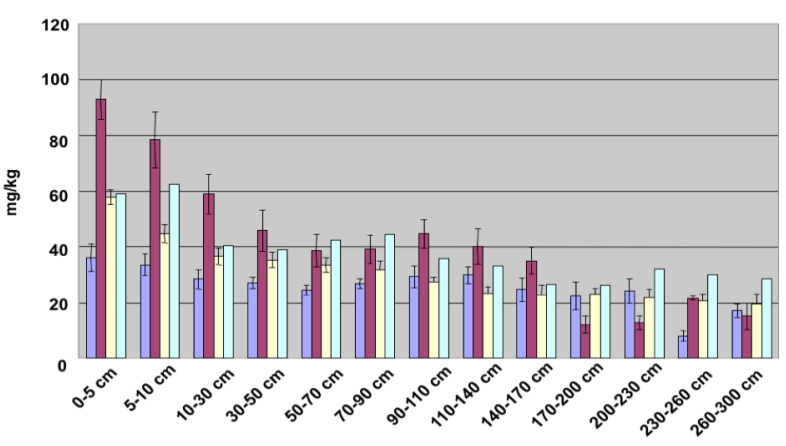

Figure 1. $\mathrm{HNO}_{3}-\mathrm{H}_{2} \mathrm{O}_{2}$-extractable copper concentration of different layers of soils (blue: Tivadar; burgundy: Vásárosnamény; yellow: Rakamaz; and light green: Tiszacsege).

Soil samples were air dried and sieved $(<2 \mathrm{~mm})$ for further analysis. The chemical analysis was carried out in accordance with a Hungarian Standard [12], using $\mathrm{HNO}_{3}$ $\mathrm{H}_{2} \mathrm{O}_{2}$ digestion, which yields total elemental contents. The extraction of the easily available metal contents was conducted according to Lakanen and Erviö [13].

Sequential extractions were performed to determine the concentration of metals associated with different operationally defined soil fractions, in the course of which, stronger and stronger extractants are used to remove metals from the sample. In this case the McGrath method [14] was used, which uses 0.1 M $\mathrm{CaCl}_{2}$ to determine water soluble and exchangeable metal fractions, $0.5 \mathrm{M} \mathrm{NaOH}$ to determine the fraction of metals bound to organic matter; $0.05 \mathrm{M} \mathrm{Na}_{2}$ EDTA to determine metals bound to carbon and finally, destruction using aqua regia determines the residual fraction. In order to obtain the standard data we used a Merck-made (E. Merck, Darmstadt, Germany) analytical grade $\mathrm{HNO}_{3}(65 \%)$ solution. Merck and BDH standard solutions were used to prepare the stock solutions, and REANAL (Budapest, Hungary) solid chemicals were used. Ultrapure water was used to prepare the solutions (Millipore, Paris, France).

Samples were analysed using an Inductively Coupled Plasma - Optical Emission Spectrometer (ICP$\mathrm{OES}$ ) to determine $\mathrm{Cu}$ content (Perkin-Elmer Optima 3300 DV; Perkin-Elmer Ltd., Shelton, USA). The Pb content was measured by a QZ 939 GF-AAS (Unicam) in 2000 and by an X7 ICP-MS (Thermo Fischer Scientific) between 2011 and 2013.

Target analytics were $\mathrm{Al}, \mathrm{Ba}, \mathrm{Ca}, \mathrm{Cd}, \mathrm{Co}, \mathrm{Cr}, \mathrm{Cu}$, $\mathrm{Fe}, \mathrm{K}, \mathrm{La}, \mathrm{Li}, \mathrm{Mg}, \mathrm{Mn}, \mathrm{Mo}, \mathrm{Na}, \mathrm{Ni}, \mathrm{P}, \mathrm{Pb}, \mathrm{S}$, and $\mathrm{Zn}$. In this study, we focused on $\mathrm{Cu}$ and $\mathrm{Pb}$, because these

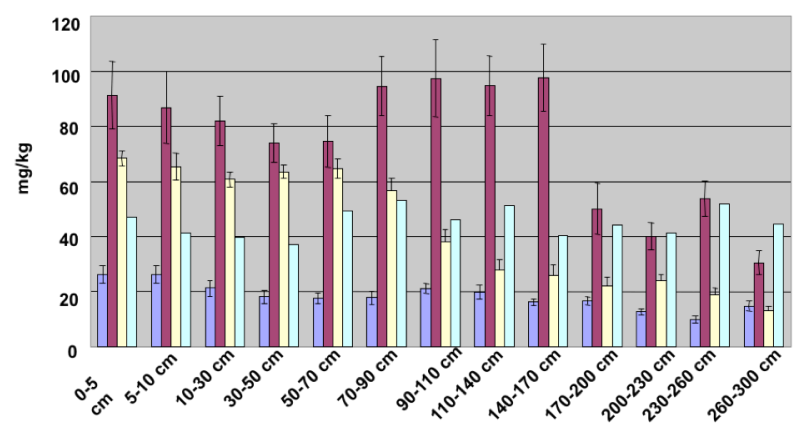

Figure 2. $\mathrm{HNO}_{3}-\mathrm{H}_{2} \mathrm{O}_{2}$-extractable lead concentration of different layers of soils (blue: Tivadar; burgundy: Vásárosnamény; and yellow: Rakamaz; light green: Tiszacsege).

elements were connected to the contamination on the floodplain. Certified standard materials used in QA/QC were BCR CRM 141R: calcareous loam soil [15]; BCR CRM 142R: light sandy soil [16], and BCR CRM 143R: sewage sludge amended soil [17]. We assumed that the investigation of the upper $30 \mathrm{~cm}$ soil layer every five years using sequential extraction could give accurate information about the changes in the bioavailability of heavy metals and the rearrangement among fractions. All statistical analyses were performed using SPSS (version 22.0).

\section{Results and Discussion}

Figs. 1 and 2 show the total elemental composition for the four sampling sites. Although replicate cores and sampling locations differ, they show an overall trend. The $\mathrm{Cu}$ content of the topsoil was higher than that of the lower layers formed earlier. Data indicates that the $\mathrm{Cu}$ and $\mathrm{Pb}$ contents of the topsoil are greater in Vásárosnamény compared to in Tivadar, possibly due to the combined effects of the two contamination incidents convening at the confluence of the rivers Tisza and Szamos. The 70 to $170 \mathrm{~cm}$ soil layers at Vásárosnamény show high lead content.

The Lakanen-Erviö soluble element content is shown in Figs.3 and 4. Data indicate that the heavy metal content of the floodplain soils is greater in Vásárosnamény compared to in Tivadar. From this point downstream, the level of contamination appears to decrease with distance, with the lowest value (data not shown) in the topsoil of the arboretum at Tiszakürt (275 river $\mathrm{km}$ ) where atmospheric deposition may be the 


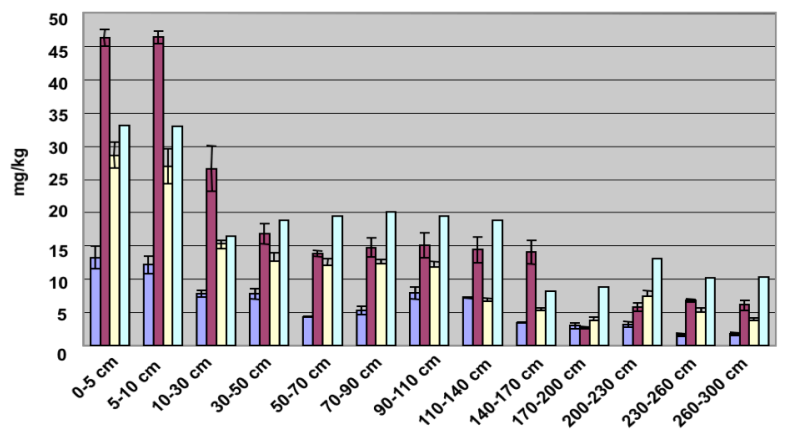

Figure 3. Ammonium-acetate-EDTA (LakanenErviö)-extractable $\mathrm{Cu}$ concentration of different layers of soils (blue: Tivadar; burgundy: Vásárosnamény; yellow: Rakamaz; and light green: Tiszacsege).

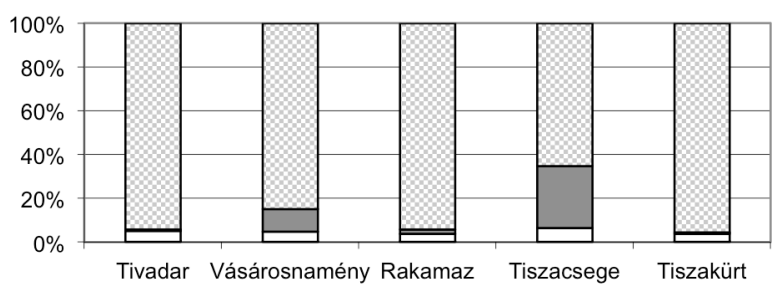

Figure 5. Proportions of the different $\mathrm{Cu}$ fractions in the topsoil (solid: $\mathrm{CaCl}_{2}$ soluble, hollow: $\mathrm{NaOH}$ soluble, small dotted: $\mathrm{Na}_{2}$ EDTA soluble, checked:aqua regia soluble).

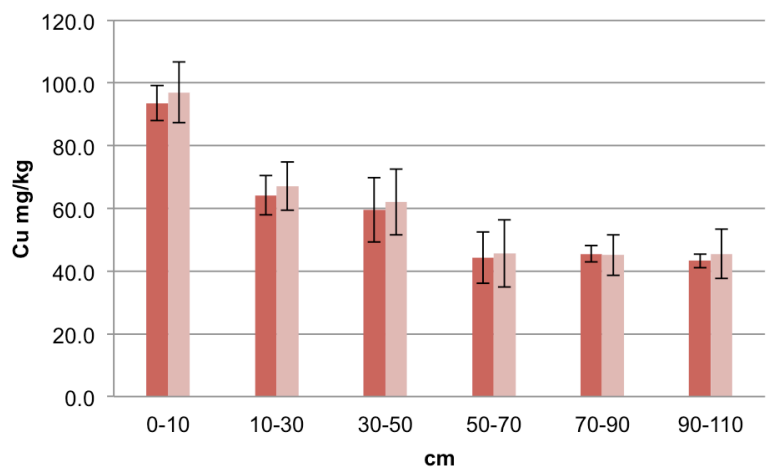

Figure 7. Total $\mathrm{Cu}$ concentration $\left(\mathrm{HNO}_{3} / \mathrm{H}_{2} \mathrm{O}_{2}\right.$ soluble) at Vásárosnamény (dark: 2002, light: 2013).

source of pollution. The $\mathrm{Cu}$ content of the upper $10 \mathrm{~cm}$ soil layer is nearly twice as high as levels measured in the other layers. The bioavailable $\mathrm{Cu}$ and $\mathrm{Pb}$ contents at Vásárosnamény exceeded the temporary limit values of Lakanen-Erviö extractable metal contents for soil contamination [18], while the upper soil layer of the Tivadar floodplain appeared to be uncontaminated.

The McGrath method of sequential extraction can be used for assessing the contents of toxic and potentially toxic elements in soil, and their biological effects, i.e. for the determination of the amounts bound to various forms of compounds in soils. The proportion of the water soluble and exchangeable fractions $\left(\mathrm{CaCl}_{2}\right.$ extraction fraction) is negligible as regards $\mathrm{Cu}$ and $\mathrm{Pb}$. The ratio of metals bound to organic matter ( $\mathrm{NaOH}$ extraction) is low, according to the expectations, as metals bound to carbonates ( $\mathrm{Na}_{2}$ EDTA extraction) is higher in the Vásárosnamény and Tiszacsege soils, but lower at the

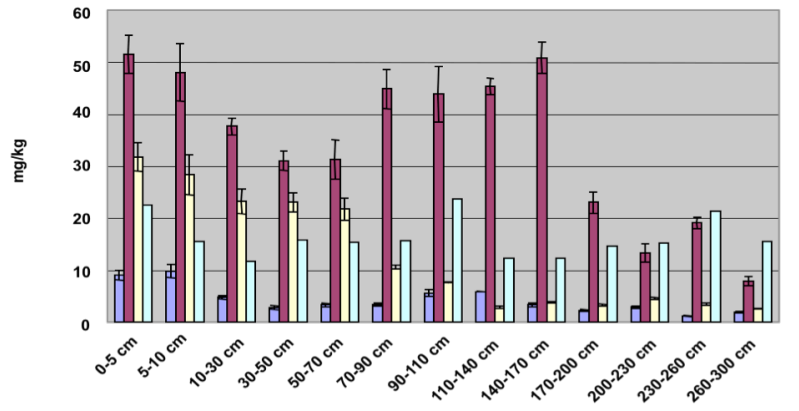

Figure 4. Ammonium-acetate-EDTA (Lakanen-

Erviö)-extractable $\mathrm{Pb}$ concentration of different layers of soils (blue: Tivadar; burgundy: Vásárosnamény; yellow: Rakamaz; and light green: Tiszacsege).

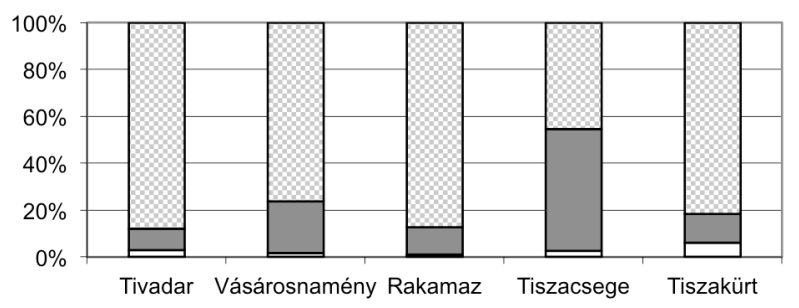

Figure 6. Proportions of the different $\mathrm{Pb}$ fractions in the topsoil (solid: $\mathrm{CaCl}_{2}$ soluble, hollow: $\mathrm{NaOH}$ soluble, small dotted: $\mathrm{Na}_{2}$ EDTA soluble, checked:aqua regia soluble).

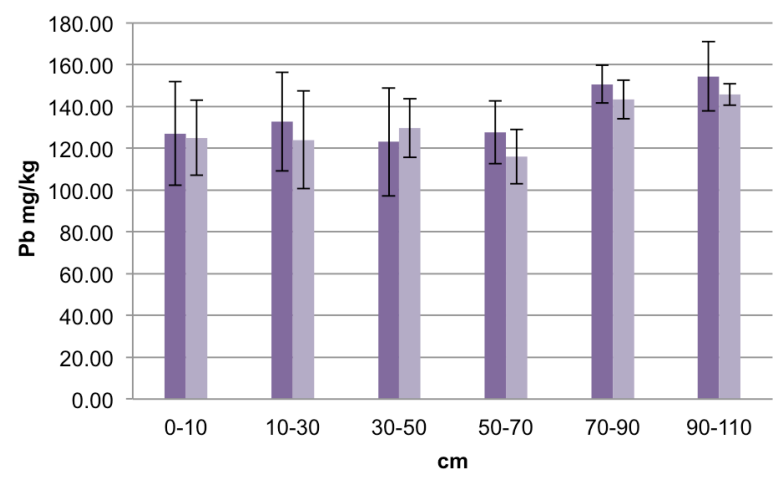

Figure 8. Total $\mathrm{Pb}$ concentration $\left(\mathrm{HNO}_{3} / \mathrm{H}_{2} \mathrm{O}_{2}\right.$

soluble) at Vásárosnamény (dark: 2002, light: 2013).

other sites. The residual fraction of metals (aqua regia extraction) is the largest amongst the samples (Figs.5 and 6).

We determined the $\mathrm{Cu}$ and $\mathrm{Pd}$ content of the floodplain soils after ten years of the previous waves of contamination. Figs.7 and 8 illustrate the vertical distribution of $\mathrm{HNO}_{3} / \mathrm{H}_{2} \mathrm{O}_{2}$ extractable $\mathrm{Cu}$ and $\mathrm{Pb}$ contents. There is no statistically proven difference between the results of the samples taken at two different times.

Figs.9-12 show the Lakanen-Erviö soluble element contents of the same core. There is no statistically significant difference between the results of the samples taken at the two different times. The effect of the second source of pollution (Baia Borsa, March 2000) on the available metal contents of the Tivadar floodplain was not detectable, which is in accordance with the results of Szabó et al. [19]. 


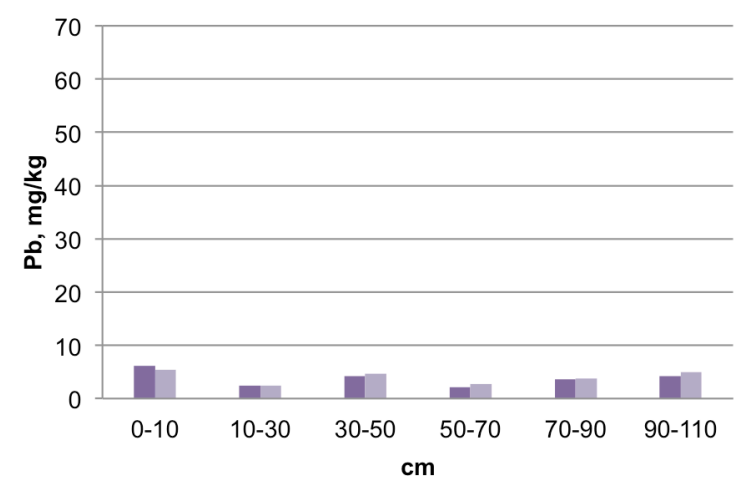

Figure 9. Soluble $\mathrm{Pb}$ contents of the $110 \mathrm{~cm}$ deep soil profile at Tivadar (dark: 2002, light: 2013).

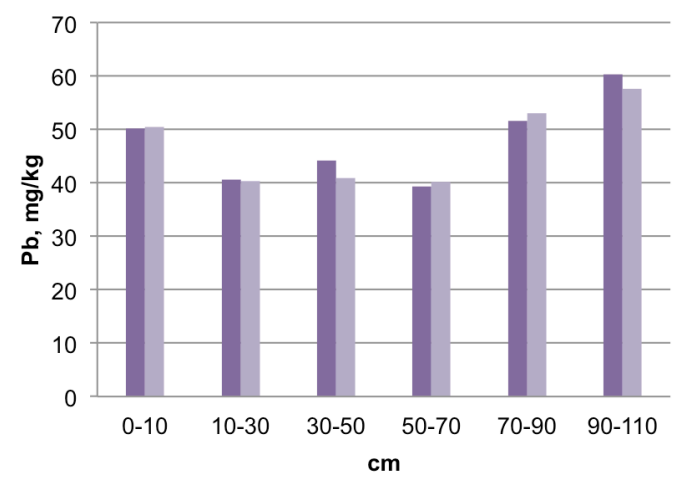

Figure 11. Soluble $\mathrm{Pb}$ contents of the $110 \mathrm{~cm}$ deep soil profile at Vásárosnamény (dark: 2002, light: 2013).

\section{Conclusion}

The $\mathrm{Cu}$ and $\mathrm{Pb}$ contents of the topsoil were found to be the highest in the upper $10 \mathrm{~cm}$ layer as a result of the latest sources of contamination. The degree of this effect varies according to the sampling sites. The lowest element content was measured at Tivadar, while samples from Vásárosnamény showed a maximum for many elements because of the first coincidence of the two pollution waves. According to the core samples, higher element contents could be found in some of the deeper layers as marks of former sources of pollution. The investigation of the upper $30 \mathrm{~cm}$ soil layer in the coming years using sequential extraction could give accurate information about the changes in the bioavailability of heavy metals and the rearrangement among fractions in addition to laboratory experiments of the effects on soil acidity.

\section{Acknowledgement}

This work was supported by KÖM 811, NSF-MTAOTKA, KTIA_AIK_12-1-2012-0012, and OTKA 108558 projects.

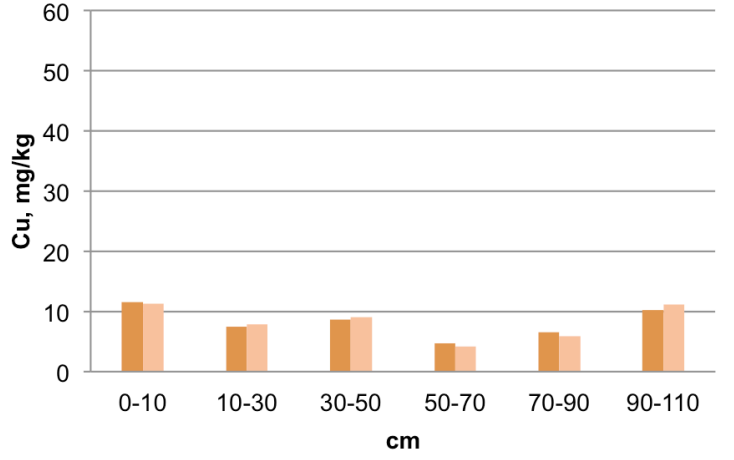

Figure 10. Soluble $\mathrm{Cu}$ contents of the $110 \mathrm{~cm}$ deep soil profile at Tivadar (dark: 2002, light: 2013).

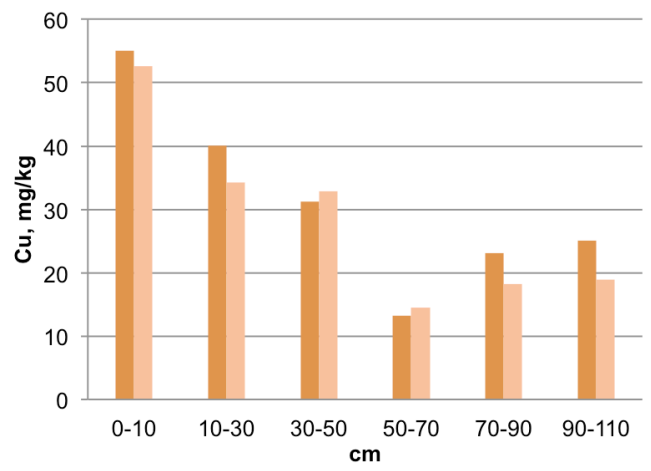

Figure 12. Soluble $\mathrm{Cu}$ contents of the $110 \mathrm{~cm}$ deep soil profile at Vásárosnamény (dark: 2002, light: 2013).

\section{REFERENCES}

[1] Nguyen, H.L.; Braun, M.; Szaloki, I.; Baeyens, W.; Grieken, R.; Van Leermakers, M.: Tracing the metal pollution history of the Tisza River through the analysis of a sediment depth profile, Water Air Soil Pollut., 2009 200, 119-132 10.1007/a11270-0131525-1

[2] Macklin, M.G.; Brewer, P.A.; Balteanu, D.; Coulthard, T.J.; Driga, B.; Howard, A.J.; Zaharia, S.: The long term fate and environmental significance of contaminant metals released by the January and March 2000 mining tailings dam failures in Maramures County, Upper Tisza Basin, Romania, Appl. Geochem., 2003 18, 241-257 10.1016j/apgeochem.2013.04.013

[3] UNEP/OCHA: Spill of Liquid and Suspended Waste at the Aurul S. A. Retreatment Plant in Baia Mare Assessment Mission Report, Geneva, 2000

[4] Bird, G.; Brewer, P.A.; Macklin, M.G.; Balteanu, D.; Driga, B.; Serban, M.; Zaharia, S.: The solid state partitioning of contaminant metals and as in river channel sediments of the mining affected Tisza drainage basin, Northwestern Romania and Eastern Hungary, Appl. Geochem., 2003 18, 15831595 10.1016/j.apgeochem.2013.04.013 
[5] Brewer, P.A.; Macklin, M.G.; Balteanu, D.; Coulthard, T.J.; Driga, B.; Howard, A.J.; Bird, G.; Zaharia, S.; Serban, M.: The tailings dam failures in Maramures county, Romania and their transboundary impacts on the river system, NATO Sci. Ser.: IV: Earth Environ. Sci., 2003 20, 73-83 ISSN: 1568-1238

[6] Győri, Z.; Alapi, K.; Sipos, P.; Zubor, Á.: Effects of heavy metals on floodplain soils and pastures of the River Tisza, Hungary II. Examination of soil and herbaceous plants in the Upper Tisza. In Natural Attenuation of Metals Along the Tisza River-Floodplain Wetlands Continuum, Eds.: Adriano, D.; Németh, T.; Győri, Z., (University of Debrecen, Debrecen, Hungary) 2003, pp. 161-173 ISBN: 963-472-726-3

[7] Osán, J.; Kurunczi, S.; Török, S.; Van Grieken, R.: $\mathrm{X}$-Ray analysis of riverbank sediment of the Tisza (Hungary): Identification of particles from a mine pollution event, Spectrochim. Acta Part B Atomic Spec., 2002 57, 413-422 ISSN: 0584-8547

[8] Wehland, F.; Panaiotu, C.; Appel, E.; Hoffmann, V.; Jordanova, D.; Jordanova, N.; Denut, I.: The dam breakage of Baia Mare - a pilot study of magnetic screening, Phys. Chem. Earth, 2002 27, 1371-1376 ISSN: 1474-7065

[9] Kraft, C.; Tümpling, W.; Zachmann, D.W.: The effect of mining in northern Romania on the heavy metal distribution in sediments of the rivers Szamos and Tisza (Hungary), Acta Hydrochim. Hyrdobiol., $2005 \quad$ 34(3), 257-264 10.1002/aheh.200400622

[10]Győri, Z.; Alapi, K.; Prokisch, J.; Németh, T.; Adriano, D.; Sipos, P.: Cd, Cu, Pb and $\mathrm{Zn}$ content of the riparian zone of the Tisza River (Hungary) after heavy metal pollution, Agrochem. Soil Sci., 2010 59, 117-124 10.1556/Agrokem.59.2010.1.14

[11] Kabata-Pendias, A.; Pendias, H.: Trace elements in soils and plants, $3^{\text {rd }}$ Ed. (CRC Press, Ltd. Boca Raton, FL USA) 2001 ISBN: 978-1-4200-9368-1

[12] MSZ 21470-50: Environment protection. Testing of soils. Determination of total and soluble toxic element, heavy metal and chromium(VI) content. Hungarian Standard, 1998 (in Hungarian with English summary)
[13]Lakanen, E.; Erviö, R.: A comparison of eight extractants for the determination of plant available micronutrients in soil, Acta Agr. Fenn., 1971 123, 223-232

[14] McGrath, S.P.; Cegarra, J.: Chemical extractability of heavy metals during and after long-term applications of sewage sludge to soil, J. Soil Sci., 1992 43, 313-321 10.1111/j1365-2389.1992.tb00139.x

[15] Quevauviller, Ph.; Muntau, H.; Fortunati, U.; Vercoutere, K.: The certification of the total contents (mass fractions) of $\mathrm{Cd}, \mathrm{Co}, \mathrm{Cr}, \mathrm{Cu}, \mathrm{Hg}$, $\mathrm{Mn}, \mathrm{Ni}, \mathrm{Pb}$ and $\mathrm{Zn}$ and aqua regia soluble contents (mass fractions) of $\mathrm{Cd}, \mathrm{Co}, \mathrm{Cr}, \mathrm{Cu}, \mathrm{Hg}, \mathrm{Mn}, \mathrm{Ni}, \mathrm{Pb}$ and $\mathrm{Zn}$ in a calcareous loam soil. (CRM 141R). BCR Information. Commission of the European Communities, 1996 ISBN 92-827-7412-0

[16] Maier, E.A.; Griepink, B.; Muntau, H.; Vercoutere, K.: Certification of the total contents (mass fractions) of $\mathrm{Cd}, \mathrm{Co}, \mathrm{Cu}, \mathrm{Pb}, \mathrm{Mn}, \mathrm{Hg}$ and $\mathrm{Ni}$ and the aqua regia soluble contents (mass fractions) of $\mathrm{Cd}, \mathrm{Pb}, \mathrm{Ni}$ and $\mathrm{Zn}$ in a light sandy soil. (CRM 142R). BCR Information. Commission of the European Communities, 1994 CD-NA-15284-EN-C

[17] Maier, E.A.; Griepink, B.; Muntau, H.; Vercoutere, K.: Certification of the total contents (mass fractions) of $\mathrm{Cd}, \mathrm{Co}, \mathrm{Cu}, \mathrm{Pb}, \mathrm{Mn}, \mathrm{Hg}$ and $\mathrm{Zn}$ and the aqua regia soluble contents (mass fractions) of $\mathrm{Cd}, \mathrm{Cr}, \mathrm{Pb}, \mathrm{Mn}, \mathrm{Ni}$ and $\mathrm{Zn}$ in a sewage sludge amended soil. (CRM 143R). BCR Information. Commission of the European Communities, 1994 CD-NA-15284-EN-C

[18] Kádár, I.: About the examination of contaminated soils. Handbook for Rehabilitation 2. (Ministry of Environmental Protection, Budapest, Hungary) 1998

[19] Szabó, Sz.; Posta, J.; Gosztonyi, Gy.; Mészáros, I.; Prokisch, J.: Heavy metal content of flood sediments and plants near the River Tisza, AGD Landscape Environ., 2008 2, 120-131 ISSN 17897556 


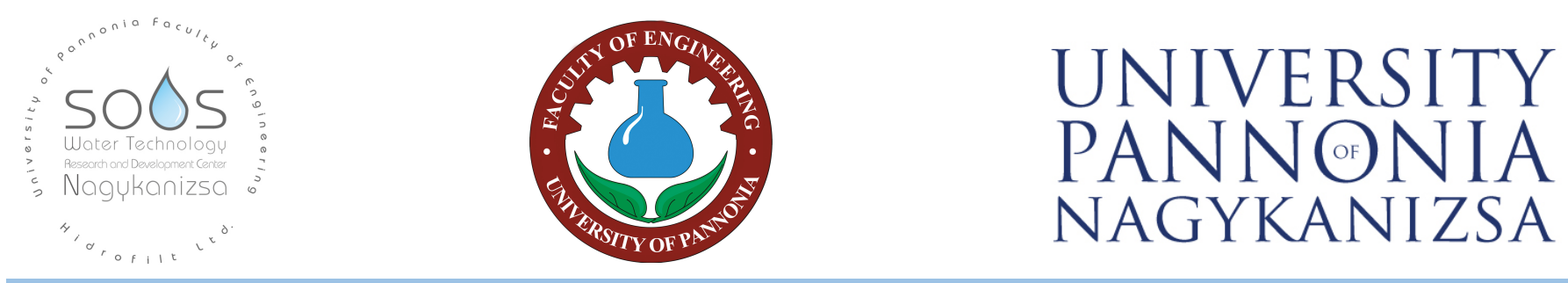

Soós Ernő Water Technology Research and Development Centre was established in 2014 by the Faculty of Engineering at the University of Pannonia, Nagykanizsa Municipality of County Rank and Hidrofilt Water Treatment Ltd. The activities at the Research Centre are built on decades of experience and expertise gained in Nagykanizsa in the field of water treatment and water purification. The goal of the Centre is to perform international-level research activities in different areas of water purification and treatment. Nagykanizsa aims to become a centre of knowledge in national and international relations as well. Besides the fundamental research, the Research Centre plays an active role in industrial development activities, putting a great emphasis on drinking water treatment, power plants, the water management of cooling towers, horticulture and irrigation water treatment, seawater desalination, pharmaceutical and infusion solutions, water supply technologies and related control procedures, and areas of measurement technology.

The areas utilising the development results include:

- Treatment methods for drinking and process water,

- Purified water, ultra pure water, and the pre-treatment of water for the injection of pharmaceuticals,

- Water treatment for horticulture and irrigation,

- Wastewater treatment in the oil and gas industries,

- Grey-water recycling,

- Seawater and brackish desalination,

- Water treatment for swimming pools,

- Monitoring and the control of water treatment, and development of instrumentation.

The Soós Ernő Research Centre is named after a pioneer in the water treatment field who was a chemical and environmental engineer. He made great contributions to the field with his innovative thinking. Several patents in water treatment are tied to his name. The desire of the research team is to advance his work by drawing on his leadership and scientific work as new frontiers in water treatment are pursued.

As an initiative of this decision, the Research Centre organised its first scientific conference in December 2014, entitled Water and Wastewater Treatment in Industry. Nearly 50 presenters attended the conference from both industry and academia with about 170 participants. Based on unanimous support, this conference has become international. In addition to industry and academia, companies from the service sector are also invited. The conference will be held on 28th October 2015, and will be preceded by a project partner meeting.

At the conference, the winners of the Soós Ernö Young Researchers Award will also be announced. This award is a scientific grant for MSc and $\mathrm{PhD}$ candidates. The candidates are invited to submit their theses for nomination from the field of water and wastewater treatment and related disciplines.

The University of Pannonia has a long tradition of academic excellence based on the training of engineering specialists for industry and the economy. The Faculty of Engineering and the Nagykanizsa Campus of the University of Pannonia are committed to forging close and productive partnerships with industry. The water and wastewater treatment system operation programme is designed for engineering and non-engineering graduates who are interested in pursuing a career within companies and organisations involved in water and wastewater treatment.

High-quality academic education is offered together with hands-on training. By participating in the study programme, state-of-the-art knowledge compatible with the current needs of industries and the most advanced water purification technologies applied are acquired. 